\title{
ISSUES OF JUDICIAL ORGANIZATION AND JURISDICTION OF COURTS OF FIRST INSTANCE IN THE REPUBLIC OF ESTONIA
}

\author{
Rinat. R. Akhmetzakirov ${ }^{1}$ \\ Idris M. Gilmanov ${ }^{2}$ \\ Muhamat M. Gilmanov ${ }^{3}$
}

\begin{abstract}
The United Nations obliges the national legislator to pay particular attention to issues of jurisdiction through the International Documents. These obligations are specified in clause 1 of Article 14 of the Covenant on Civil and Political Rights and in clause 1 of Article 6 of the Convention for the Protection of
\end{abstract} Human Rights and Fundamental Freedoms. It is the duty of states to guarantee rights to a fair public hearing by a competent court without delay. Jurisdiction issues, i.e. competencies of criminal courts in the Russian Federation, are regulated by Article 31 of the Criminal Procedure Code of the Russian Federation. The rules of this article are of great importance. Thus, the fulfillment of the requirements of Article 31 of the Criminal Procedure Code of the Russian Federation consists in the fact that if the rules of this article are violated, this automatically leads to the sentence cancellation and the reexamination of the criminal case. Similar serious attention is paid to the legislator of the Republic of Estonia. The legal system of this country is part of the Romano-German legal family, having peculiar differences. In order to alleviate the workload of the courts of first instance, offenses were singled out in the Criminal Code as an independent form of punishment, and the simplified (summary) proceedings were also stipulated for application.

Keywords: composition of crimes, jurisdiction of the magistrate, simplified (summary) production, simplified (accelerated) proceedings, maximum sanctions.

\footnotetext{
${ }^{1}$ Kazan Federal University

${ }^{2}$ Kazan Federal University. 89027186336

${ }^{3}$ Kazan Federal University. e-mail: muhamat74@yandex.ru tel. 89027195575
} 


\section{Sireite}

Periódico do Núcleo de Estudos e Pesquisas sobre Gênero e Direito Centro de Ciências Jurídicas - Universidade Federal da Paraíba V. 8 - No 07 - Ano 2019 - Special Edition ISSN | 2179-7137 | http://periodicos.ufpb.br/ojs2/index.php/ged/index

\section{Introduction}

Russian legislation prevailed in this country in the field of criminal law and process. In 1889, the judicial statutes of Russia were extended to the Baltic states, i.e. the 1864 Charter. In November 1940, the Soviet Union enacted the legislation of the USSR on the territory of Estonia: criminal, criminal procedure, civil procedure, etc. However, we should note that Estonia had only its own codes by the beginning of the 1960s.

Now it is necessary to pay attention to the criminal procedure legislation of Russia. Thus, with the adoption of the new Criminal Procedure Code in late 2001, the maximum sentence that a magistrate could impose was increased from 2 to 3 years in prison. As a result, not only minor crimes, for which they were created, but also a part of the composition of crime of medium gravity, passed to the jurisdiction of the magistrates of Russia. In the subsequent, the maximum penalty for committing crimes of minor gravity was also increased from 2 to 3 years in prison in Article 15 of the Criminal Code of the Russian Federation by the Federal Law No. 420-FZ dated December 7, 2011. In
73

our opinion, these changes were intended to reduce the burden of not just the judges of federal courts, but the magistrates.

\section{Materials and methods}

This scientific article was written using comparative procedural research methods as applied to the regulatory legal acts of the Russian Federation, its brief analysis is set out taking into account all previously adopted procedural laws.

Jurisdiction of the courts in criminal matters of the Russian Federation is regulated by Article 31 of the Criminal Procedure Code $[1$, p. 28 29]. This Code provides a list of compositions of crimes from the Criminal Code of the Russian Federation, the sanctions of which are not more than 3 years in prison [2]. From 2000 to July 1, 2002, the upper limit was 2 years [3, p. 21, 205]. However, since December 7, 2011, Article 15 of the Criminal Code was changed, and the maximum punishment for committing crimes of minor gravity was increased from two to three years in prison [4, $\mathrm{p}$. 14-19]. It should be noted that the requirements of this article are essential. 
A gross violation of the jurisdiction rules in criminal cases leads to an automatic cancellation of the sentence, reexamination of the criminal case, and doubled cash costs.

In the course of this study, we used general scientific and special methods of the science - observation, historical, integrative methods, comparative, structural and forensic, systemic-structural and other research methods.

\section{Results and discussion}

As mentioned earlier, Estonian criminal and criminal procedural legislation was based on the relevant Russian legislation. The judicial statutes of Russia of 1864 were extended to the Baltic states since 1889. In November 1940, the Presidium of the Supreme Soviet of the USSR introduced the legislation of the USSR on the territory of Estonia: criminal, criminal procedure, etc As mentioned above, this country started having its own codes only in the early 1960s. That is why we will compare the criminal, criminal procedure legislation of Russia.

It is important to note that the Estonian legal system has rapidly transformed from the Soviet to the classical Romano-German law in the last decade.

The Constitution of the Republic of Estonia dated June 28, 1992 is in force as amended on October 5, $2003[5,13,16]$. In courts, the criminal cases are heard according to $\$ 5$ of Chapter 1 of the Constitution and Article 10 of the Criminal Procedure Code of the Republic of Estonia, in the state language of Estonia, i.e. in Estonian.

Turning to the criminal legislation of this country, we should note that from March 1, 2002, the Penal Code (hereinafter - the Criminal Code, for convenience), adopted by the legislator on June 6, 2001, came into force in Estonia. It replaced the Criminal Code of 1961, which acquired a new edition in 1992. For example, Article 10 shows the ages from which criminal liability arises - it is 15 years for committing all types of crimes, and 13 years - for committing serious crimes.

Article 4 of the Criminal Code "Severity of Crime" stipulates only two degrees of severity of crimes, although three degrees were earlier provided under the same name in Article 7.2 of the previous Criminal Code of 1961. Crimes 
of the first degree include crimes for the commission of which a court may sentence to more than five years in prison or life imprisonment; for the commission of crimes of the second degree - imprisonment for up to five years or a pecuniary punishment, i.e. fine (according to Article 47 of the Criminal Code, from 3 to 300 fine units, the base unit is 4 euros).

Let us present three degrees of crimes of the previous Criminal Code. Thus, the first degree included intentional or reckless acts, for the commission of which the Code stipulated punishment of more than eight years in prison or life imprisonment; second degree - up to 8 years in prison; third degree - a fine (according to Article 28 of the Criminal Code, up to nine hundred daily rates), deprivation of the right to occupy certain positions or being engaged in certain activities, or arrest (according to Article 23.2 of the Criminal Code, up to 3 months).

Section 2 of the Criminal Code provides penalties for committing an offense. Firstly, this is a fine (Article 47 of the Criminal Code, starting from 4 euros); secondly, arrest (Article 48 of the Criminal Code) up to 30 days (previously it was up to 3 months), thirdly, deprivation of the right to drive vehicles for up to 2 years. The specified allocation of offenses as an independent form of punishment is a feature of the approach of the national legislator to the categories of crimes. A similar proposal has been discussed by the scientists and practitioners in Russia in recent years. In our opinion, this is a completely correct proposal, which shall be specified, supported and introduced into the current legislation.

On February 12, 2003, the Criminal Procedure Code was adopted in Estonia, which entered into force on July 1,2004 . This document is in force from September 26, 2013 [6], it replaced the Criminal Procedure Code of 1961. Thus, Article 18 of the Criminal Procedure Code provides that the county and city courts composed of the presiding judge and two people's judges consider criminal cases on crimes of the first degree (according to Article 4 of the Criminal Code, more than 5 years in prison or life imprisonment). Criminal cases of the second degree (up to 5 years in prison) and criminal cases in the simplified proceedings are examined by a judge alone. Moreover, the preliminary 
hearing of the cases is also carried out by the judge alone. According to the requirements of Article 21 of the Criminal Procedure Code, the preliminary investigation judge, i.e. one of the judges of a county or city court, also performs these functions alone.

There is an executive judge in the staff of a county or city court (Article 22 of the Criminal Procedure Code), whose functions include sole enforcement of court decisions. Article 24 of the Criminal Procedure Code gives general jurisdiction, which is limited only to the relevant territory of the district.

For comparison, let us cite the example of a united Germany, in which, as in the Republic of Austria, district courts function as the lowest level of the judicial system [7]. The jurisdiction of district courts is regulated by the Federal Law on the Judicial System [8]. To some extent, we can find the district judges in Germany similar to the magistrates of Russia, since the functioning of the latter is also organized on a territorial basis (judicial sections).

Let us return to the Criminal Procedure Code of the Republic of Estonia. According to Article 31 of the
Criminal Procedure Code "Classification of Investigative Bodies", the Investigative Bodies primarily include the Police Department, as well as other bodies, in particular, the Central Criminal Police, the Security Police Department, the Tax and Customs Board, etc.

Chapter 8 of the Criminal Procedure Code is devoted to questions of pre-trial proceedings - Articles 193210. In addition, we should note the requirements of Article 212 of the Criminal Procedure Code, which is called "Jurisdiction", and it states that the pre-trial proceedings are conducted by the Police Department, as well as the relevant authorities listed above.

The simplified proceedings, which are discussed in Chapter 9 of the same name, are of particular interest. Simplified proceedings has 3 varieties: 1) shortened proceedings, 2) conciliation proceedings, and 3) proceedings by judicial order. Thus, Section 1 sets out the provisions of shortened proceedings - Article 233-238 of the Criminal Procedure Code. The grounds for applying shortened proceedings are as follows: 1) presence of petition of the accused person and 2) consent of the 
prosecutor. In this case, the court, on the basis of Article 233 of the Criminal Procedure Code, can consider a criminal case, based only on the case files, and without calling witnesses and experts. Article 234 of the Criminal Procedure Code provides restrictions on the use of shortened proceedings. Thus, these conditions cannot be applied in the criminal cases on crimes for the commission of which the Criminal (Penitentiary) Code stipulated life imprisonment; in criminal cases in respect of several accused persons, if at least one of them does not agree with the application of these proceedings. At the same time, the legislator indicated that the shortened proceedings are carried out according to the rules of Chapter 10 of the Criminal Procedure Code.

The appeal instances were introduced as a result of the reform of the criminal process in Estonia. This instance did not exist in the country, as in Russia, where it was also introduced two years ago. It is important to note that these norms were not included in the Criminal Procedure Code, but in a separate Code of Appeal and Cassation Proceedings in Criminal Cases of 1993 in Estonia. Moreover, this approach of the legislator diverges from the panEuropean one. It should be noted that there are two district courts in the Estonian territory: Tallinn and Tartu County Courts of Appeal. Based on this, all decisions of judges of the county courts are appealed to these courts.

Analyzing the lower courts, it should be noted that four county courts operate in the country: Viru, Pärnu, Tartu and Harju County Courts. These courts have serf departments that register the land register on property rights to real estate, and register departments that maintain a commercial register of entrepreneurs and organizations. Their activities can be attributed to the notarial acts. It should be noted that the functions are performed by the department of payment orders for expedited consideration of applications in the Pärnu County Court [9, p. 9]. This approach, aimed at using accelerated proceedings to relieve the workload of first instance courts, deserves serious attention. The Tort Procedure Code, which entered into force on May 22, 2002, deserves similar attention. The Code is currently in force as amended on June 19, 2013 and is also of particular 
interest, the analysis of which can be given in another work $[10,14,15]$.

\section{Conclusions}

This article is based on a comparative analysis of the jurisdiction of the courts of first instance of the Republic of Estonia, Russia and individual European countries. The gross violations of the rules of jurisdiction and the re-examination of cases lead to increased cash costs from the budget. Such severe financial consequences for the state budgets are completely unprofitable. In addition, national procedural legislation that meets the requirements of international documents shall have grounds for applying expedited (summary) proceedings, usually up to 5 years in prison.

\section{Summary}

The above comparative analysis of the jurisdiction of the courts of first instance of the Republic of Estonia and Russia shows that the regulation of jurisdiction between the courts of first instance, as well as legislatively thoughtout rules of simplified (expedited) proceedings, which were successfully chosen by the legislator, make it possible to solve the problems of public access to justice. In addition, while avoiding violations of the jurisdiction rules, a positive consequence for the states is represented by a reduction in budget expenditures.

The successful use of simplified (accelerated) proceedings in the national laws will allow solving the problem of congestion of the courts of first instance of both the Republic of Estonia and other states, which should be taken into service.

\section{Acknowledgements}

The work is performed according to the Russian Government Program of Competitive Growth of Kazan Federal University.

\section{References:}

Criminal Procedure Code of the Russian Federation. - M.: Prospekt. 2018. P. 2829.

Criminal Code of the Russian Federation. - M.: Prospekt, 2018.

Criminal Procedure Code of the RSFSR. - M.: "Prospect". 2000. P. 21, 205. 
Criminal Code of the Russian Federation. - M.: Prospekt. 2012. P. 1419.

Constitution of the Republic of Estonia dated June 28, 1992, Eesti Vabariigi pohiseadus // Published (Avaldamismarge): RT 1992, 26, 349; RT I 2003, 64, 429.

Criminal Procedure Code of the Republic of Estonia dated February 12, 2003, Kriminaalmenetluse seadustik // Published (Avaldamismarge): RT I 2003, 27, 166; RT I, 04.10.2013, 3.

Criminal Procedure Code of Germany $\begin{array}{llll}\text { dated } & \text { February } & 1, & 1877\end{array}$ (CPC),Strafprozessordnung, Munchen. 2009.

Federal Law on the Judicial System of Germany dated January 27, 1877, Gerichtsverfassungsgesetz (GVG) //Zivilprozessordnung, Deutscher Taschenbuch Verlag GmbH \& Co. KG, Munchen 2010.

Ermoshin G.T. Organization of the judiciary in the Republic of Estonia // Russian Justice, 2014, No. 9. P. 9.
Tort Procedure Code, 2002, Vaarteomenetluse seadustik // Published (Avaldamismarge): RT I 2002, 50, 313; RT I, 06.07.2013, 3.

Muyambiri, B., \& Chabaefe, N. N. (2018). The Finance-Growth Nexus in Botswana: A Multivariate Causal Linkage. Dutch Journal of Finance and Management, 2(2), 03.

Santana, L. F., dos Santos, L. F. C., Silva, T. S. C., Villar, V. B., Rocha, F. G., \& Gonçalves, V. (2017). Scrum as a Platform to Manage Students in Projects of Technological Development and Scientific Initiation: A Study Case Realized at UNIT/SE. Journal of Information Systems Engineering \& $\begin{array}{lll}\text { Management, } & 2(2), & 7 .\end{array}$ https://doi.org/10.20897/jisem.201707

Matandare, M. A. (2018). Botswana Unemployment Rate Trends by Gender: Relative Analysis with Upper Middle Income Southern African Countries (2000-2016). Dutch Journal of Finance and Management, 2(2), 04. 
de Almeida Cruz, J. J., \& de Azevedo

Silva, K. K. (2017). Relational Algebra

Teaching Support Tool. Journal of

Information Systems Engineering \&

Management, 2(2), $\quad 8$.

https://doi.org/10.20897/jisem.201708

Vieira Alves, F. R. (2018). The

Quaterniontonic and Octoniontonic

Fibonacci Cassini's Identity: An

Historical Investigation with the Maple's

Help. International Electronic Journal of

Mathematics Education, 13(3), 125-138.

https://doi.org/10.12973/iejme/2703

Issaliyeva, A., Ospanova, A. N., \& Alibekul, A. (2018). Kazakhstan and GCC: Islamic component in joint collaboration. Opción, 34(85-2), 205220 